\title{
AXiological Aspects of the Concept of Love
}

\author{
Kalina MicheVA-PEyCheVA \\ INSTITUTE FOR BULGARIAN LANGUAGE, BULGARIAN ACADEMY OF SCIENCES \\ kalina.micheva@gmail.com
}

The paper examines the semantic realizations and verbalizations of the concept of love in the history of the Bulgarian language and in the traditional culture. The author has studied linguistic data found in Old Bulgarian manuscripts from the $9^{\text {th }}-11^{\text {th }} \mathrm{c}$. The system of words and phrases that represent the concept of love and its distribution in different cultural contexts are analyzed in relation to the Christian ideas of the Middle Ages. The most important features of the concept of love in the traditional culture are represented through axiological and linguistic analysis of Bulgarian proverbs.

Keywords: history of the Bulgarian language, Christianity, proverbs, traditional culture

\section{REFERENCES}

Arnaudov 1968: Arnaudov, M. Ochertsi po balgarskia folklor [Essays in Bulgarian Folklore]. Sofia, Balgarski pisatel.

Badalanova 1993: Badalanova, Fl. Folkloren erotikon [Folk Erotikon]. T. 1, 2, 3, 4, Sofia, ROD.

Bartminski 2014: Bartminski, Y. Sedem klyuchovi ponyatia na kognitivnata lingvistika [Seven Key Concepts of Cognitive Linguistics]. - Balgarski folklor, 4, 399-407.

Biblia 1998: Biblia sirech Knigite na Sveshtenoto pisanie na Vethia i Novia zavet [Bible. Books of the Holy Scriptures of the Old and New Testaments]. Sofia, Sv. Sinod na Balgarskata tsarkva.

Bonchev 2002, 2012: Bonchev, At. Rechnik na tsarkovnoslavyanskia ezik [Dictionary of the Church Slavonic Language]. T. I (2002), T. II (2012). Sofia, Narodna biblioteka „Sv. Sv. Kiril i Metodiy“.

Grigorov, Katsarov 1986: Grigorov, M., K. Katsarov. Balgarski poslovitsi i pogovorki [Bulgarian Proverbs]. Sofia, Nauka i izkustvo.

Kitanova 2009: Kitanova, M. Otnosheniyata mezhdu roditeli i detsa spored balgarskite poslovitsi [Relations between Parents and Children in the Bulgarian Proverbs]. - Balgarski ezik, 2, 46-55.

Kitanova 2010: Kitanova, M. Kontseptat semeystvo v balgarskite poslovitsi i pogovorki [The Concept of Family in the Bulgarian Proverbs]. - In: Etnolingvistichni etyudi. Veliko Tarnovo, IK „Znak 94“, 99-134. 
Kitanova 2015: Kitanova, M. Rod, sem'a i dom v bolgarskoi iazyke i cul'ture [Kin, Family and Home in the Bulgarian Language and Culture]. Saarbrucken: LAP LAMBERT Academic publishing.

Lakoff, Dzhonson 2004: Lakoff, Dzh., M. Dzhonson. Metafory, kotorymi my zhivem [Metaphors we Live by]. Moskva, Izdatelstvo URSS.

Micheva 2015: Micheva, $V$. Kartinata na sveta v ezika na novobalgarskite damaskini [The Picture of the World in the Language of New Bulgarian Damaskins]. Sofia, DioMira.

Micheva 2016: Micheva, $V$. Svet i tma, svoe i chuzhoe v hristianskoi paradigme [Light and Dark, Own and Foreign Space in the Christian Paradigm]. Saarbrucken: LAP LAMBERT Academic publishing.

Micheva 2017: Micheva, $V$. Lyubovta i smartta v starobalgarskite klasicheski proizvedenia [Love and Death in Old Bulgarian Classical Writings]. - Balgarska rech, kn. 1, 82-89.

Micheva-Peycheva 2013: Micheva-Peycheva, K. Sblasakat na chistotata i nechistotata v balgarskata kultura i ezik [The Clash between Purity and Impurity in the Bulgarian Culture and Language]. Sofia, Izdatelstvo „Valentin Trayanov“.

Micheva-Peycheva 2016: Micheva-Peycheva, K. Sakralynaya chistota i profannaya nechistota [Sacral Purity and Profane Impurity]. Saarbrücken, LAP LAMBERT Academic Publishing.

Micheva-Peycheva 2017: Micheva-Peycheva, K. Etnokulturnata binarnost v srednovekovnata balgarska literatura [Ethnocultural Binarity in the Bulgarian Medieval Literature]. Sofia, DioMira.

Mihaylova-Stalyanova, Genev-Puhaleva 2005: Mihaylova-Stalyanova, N., Il. Genev-Puhaleva. Ezikovata kartina na lyubovta v balgarskia i polskia ezik [The Linguistic Picture of Love in the Bulgarian and Polish Language]. - In: Kak s dumi se pravyat svetove. Sofia: UI „Sv. K1. Ohridski“, 322-328.

Mikova 2018: Mikova, L. Ezikovata kartina na lyubovta v starobalgarskia i cheshkia ezik [The Linguistic Picture of Love in the Old Bulgarian and Czech Language]. - Sapostavitelno ezikoznanie, 1, 43-54.

Nicheva i dr. 1974, 1975: Nicheva, K., S. Spasova-Mihaylova, Kr. Cholakova. Frazeologichen rechnik na balgarskiya ezik [Phraseological Dictionary of the Bulgarian Language]. T.1 (1974); T. 2 (1975). Sofia, Izdatelstvo na BAN.

Parvanov 2017: Parvanov, K. Glagoli sas znachenie 'obicham' v istoricheski i savremenen plan [Verbs Meaning 'love' in a Historical and Contemporary Perspective]. - Balgarski ezik i literatura, 59, 1, 28-39.

Petrova 2013: Petrova, $R$. Balgarski paremii za prismeh i pohvala [Bulgarian Proverbs about Derision and Praise]. Ruse, Universitetski izdatelski tsentar pri RU „A. Kanchev“.

Sedakova 2018: Sedakova, I. Kontsept „lyubov“v etnolingvisticheskom osveshtenii (na bolgarskom i inoslavyanskom materiale) [The Concept of love in an Ethnolinguistic Perspective (Based on Material from Bulgarian and other Slavic Languages)]. - In: Slavyanskoe yazykoznanie. XVI Mezhdunarodnyi saezd slavistov. Belgrad, 20 - 27 avgust 2018. Doklad rossistkoi delegatsii. Moskva, Institut slavyanovedenia, RAN, 472-489. 
Serebrennikova 2011: Serebrennikova, E. F. Aspekty aksiologicheskogo lingvisticheskogo analiza [Aspects of Axiological and Linguistic Analysis]. - In: Lingvistika i aksiologia. Moskva, Tezaurus, 7-26.

Slaveykov 1972: Slaveykov, P. R. Balgarski pritchi ili poslovitsi i harakterni dumi [Bulgarian Proverbs and Specific Words]. Sofia, Balgarski pisatel.

Starobalgarski rechnik I 1999: Starobalgarski rechnik [Dictionary of the Old Bulgarian Language]. T. I (1999). Sofia, Izdatelstvo „Valentin Trayanov“.

Starobalgarski rechnik II 2009: Starobalgarski rechnik [Dictionary of the Old Bulgarian Language]. T. II (2009). Sofia, Izdatelstvo „Valentin Trayanov“.

Staroslavyanskii slovar' 1999: Staroslavyanskiy slovar [Dictionary of the Old Slavic Language]. Moskva, Russkiy iazyk.

Trendafilova 2014a: Trendafilova, P. Modelirane na poslovitsi i pogovorki, povliyani ot hristiyanstvoto [Modeling of Proverbs Influenced by Christianity]. Ruse, Universitetski izdatelski tsentar pri RU „A. Kanchev“.

Trendafilova 2014b: Trendafilova, $P$. Lingvokulturologichno izsledvane na balgarski i ruski poslovitsi i pogovorki [Linguculturological Study of Bulgarian and Russian Proverbs]. Ruse, Universitetski izdatelski tsentar pri RU „A. Kanchev“.

Tsibranska-Kostova 2011: Tsibranska-Kostova, M. Pokaynata knizhnina na Balgarskoto srednovekovie IX-XVIII v. (ezikovo-tekstologichni i kulturologichni aspekti) [Penitential Bulgarian Medieval Literature IX-XVIII c. (Linguistic, Textological and Culturological Aspects)]. Sofia, Izdatelstvo „Valentin Trayanov".

Vitanova 2013: Vitanova, M. Chovek i svyat, Lingvokulturologichni prouchvania [Man and World. Linguculturological Studies]. Sofia, Bul-Koreni.

Wittgenstein 1994: Wittgenstein, L. Kulytura i tsennosty [Culture and Values]. - In: Filosofskie raboty, Ch. 1. Moskva, Gnozis.

Vorkachov 2003: Vorkachev, S. G. Kontsept lyubvi v russkom yazykovom soznanii [The Concept of Love in the Russian Linguistic Consciousness]. - In: Kommunikativnye issledovania. Sovremennaya antologia. Volgograd, Peremena, 189-208.

Vorkachov 2013: Vorkachev, S. G. Studia selecta: izbrannye raboty po teorii lingvokulturnogo kontsepta [Studia Selecta: Selected Works in the Theory of Linguculturological Concepts ]. Volgograd, Paradigma.

Assist. Prof. Kalina Micheva-Peycheva, PhD Department of Ethnolinguistics Institute for Bulgarian Language, Bulgarian Academy of Sciences 52 Shipchenski prohod, B1. 17, 1113 Sofia, Bulgaria 